\title{
Cytosolic Calcium Elevation and cGMP Production Induced by Serotonin in a Clonal Cell of Glial Origin
}

\author{
A. Ogura, K. Ozaki, Y. Kudo, and T. Amano \\ Department of Neuroscience, Mitsubishi-Kasei Institute of Life Sciences, Machida-shi, Tokyo 194, Japan
}

\begin{abstract}
It has been shown recently that astroglial cells of the mammalian CNS possess receptors for neurotransmitters. In order to analyze what sequences of cellular events occur upon activation of these glial receptors, we utilized a 5-HT receptor in a rat clonal cell of glial origin as a model system. When the C6BU-1 glioma cells were exposed to $5-\mathrm{HT}$, the cytosolic $\mathrm{Ca}^{2+}$ concentration $\left(\left[\mathrm{Ca}^{2+}\right]_{i}\right)$ was elevated and the cellular content of cGMP was increased in a dose-dependent manner. 5-HT receptor antagonists and a $\mathrm{Ca}^{2+}$ entry blocker suppressed the increases in both $\left[\mathrm{Ca}^{2+}\right]_{i}$ and cGMP. The magnitude of the cGMP increment depended on the environmental $\mathrm{Ca}^{2+}$ concentration and was totally blocked by $\mathrm{Ca}^{2+}$ depletion. Application of a $\mathrm{Ca}^{2+}$ ionophore increased $\left[\mathrm{Ca}^{2+}\right]_{\mathrm{i}}$ and cGMP. There was a tendency for extremely high $\left[\mathrm{Ca}^{2+}\right]_{i}$ to suppress the cGMP increment. On the contrary, membrane-permeable cyclic nucleotide analogs failed to increase $\left[\mathrm{Ca}^{2+}\right]_{\mathrm{i}}$. These results suggest that the following sequence of events occurs in 5-HT-induced C6BU-1 cells: activation of 5-HT receptors, $\mathrm{Ca}^{2+}$ influx, a rise in $\left[\mathrm{Ca}^{2+}\right]_{\mathrm{i}}$ activation of guanylate cyclase, and, finally, activation of cyclic nucleotide phosphodiesterase.
\end{abstract}

Astroglial cells exert multiple functions in support of neural activities. They aid in the physiological maintenance of brain structure, and they transfer nutrients and neurotransmitter precursors to neurons. Elimination of excess potassium ion and transmitters resulting from the neuronal activity is regulated by astroglia. In the case of brain injury, their proliferation can heal many lesions. It is also believed that they secrete protein-like factors that affect neuronal differentiation (for glial functions, see Trehearne, 1981; Varon and Somjen, 1979). For the differential expression of one particular astroglial function, specific signal molecules are thought to be transferred from neuron to glia, though the nature of these signals is still unknown.

We suggest that the neurotransmitters per se may function as signal molecules in specific instances, since recent findings indicate that receptors for neurotransmitters are present in mammalian astroglial cells. Hösli et al. (1982) and Hirata et al. (1983) showed that rat brain astrocytes in culture responded to applied catecholamines with membrane de- and hyperpolarizations through activations of $\alpha$ - and $\beta$-receptors, respectively. Bowman and Kimelberg (1984) showed that glutamate and aspartate induced depolarizations, while Hösli et al. (1984) demonstrated that histamine evoked hyperpolarization of the rat brain astrocyte membrane. We also reported that a rat glioma (astrocy-

\footnotetext{
Received Oct. 2, 1985; revised Feb. 21, 1986; accepted Mar. 18, 1986.

We are grateful to Drs. Y. Kawasaki, H. Sugino, and N. Wakayama for helpful comments; to Ms. M. Miyamoto for technical assistance; and to Dr. A. Edgar for a critical reading of the manuscript. We thank Farmitalia and Sandoz for supplies of metergoline and 8-hydroxydipropylaminotetralin, respectively.

Correspondence should be addressed to Dr. Akihiko Ogura, Department of Neuroscience, Mitsubishi-Kasei Institute of Life Sciences, Minamiooya 11, Machida-shi, Tokyo 194, Japan.

Copyright (c) 1986 Society for Neuroscience $0270-6474 / 86 / 092489-06 \$ 02.00 / 0$
}

toma) clone C6BU-1 cell responded to 5-HT with a slow hyperpolarization accompanied by an increase in potassium conductance (Ogura and Amano, 1984). Alteration of potassium permeability of the glial membrane should greatly influence the homeostasis of extracellular potassium concentration in the neuronal environment.

Taking this 5-HT receptor phenomenon in the C6BU-1 cell as a model system for analysis of the glial receptors for neurotransmitters, we recently showed that an elevation of the cytosolic calcium ion concentration $\left(\left[\mathrm{Ca}^{2+}\right]_{i}\right)$ was triggered by the application of a low dose of 5-HT (Sugino et al., 1984). The potassium permeability increase reported previously should thus be a consequence of the $\left[\mathrm{Ca}^{2+}\right]_{\mathrm{i}}$ elevation. Since $\left[\mathrm{Ca}^{2+}\right]_{i}$ is one of the best-known factors for the regulation of a wide variety of cellular activities, including cytoskeletal reorganization and secretory behavior (Campbell, 1983), the receptor-coupled Ca ${ }^{2+}$ entry could play a regulatory role in glial functioning.

In further analyzing the 5-HT response in the C6BU- 1 cell, we found that application of low doses of 5-HT caused a remarkable enhancement of the cellular content of cGMP as a result of the increase in $\left[\mathrm{Ca}^{2+}\right]_{\mathrm{i}}$. Although astroglial cells in situ have not been subjected to investigations on the coupling between the neurotransmitter receptor and $\mathrm{Ca}^{2+}$ and guanylate cyclase (the presence of guanylate cyclase and cGMP in astroglial cytosol has been revealed immunohistochemically- see Ariano et al., 1980; Zwiller et al., 1981), the present results strengthen the possibility that neurons regulate the activities of surrounding glial cells through neurotransmitters.

\section{Materials and Methods}

\section{Cells}

The $\mathrm{C} 6$ cell clone was derived from a rat brain tumor induced by an application of $N$-methylnitrosourea (Benda et al., 1968). The C6BU-1 clone, used in the present report, is a bromodeoxyuridine-resistant variant of the $\mathrm{C} 6$ clone. This mutation was originally introduced for the purpose of selection in cell hybridization (Amano et al., 1974). The cell's characteristics, other than the bromodeoxyuridine-resistance, are common to the parental $\mathrm{C} 6$ clone.

The C6BU-1 cells were maintained in a humidified atmosphere of $90 \%$ air $/ 10 \% \mathrm{CO}_{2}$ with a medium composed of $95 \%$ Dulbecco's modified Eagle's medium (Gibco) and 5\% precolostrum newborn calf serum (Mitsubishi Chemical Ind., Tokyo).

Two to $3 \mathrm{~d}$ before experimentation, the cells were plated on $35 \mathrm{~mm}$ plastic dishes (Falcon) at a density of $1 \times 10^{6}$ cells/dish (for cyclic nucleotide assays) or on $100 \mathrm{~mm}$ dishes (Falcon or Corning) at the density of 5-10 × $10^{6}$ cells/dish (for fluorimetry).

\section{Cyclic nucleotide assay}

The cellular contents of $\mathrm{cG}(\mathrm{A}) \mathrm{MP}$ were determined employing commercially available radioimmunoassay kits (Yamasa Shoyu Co., Chiba) and following the protocol of Honma et al. (1977). A brief description follows.

The dish carrying the cells was washed 3 times with a basal salt solution (BSS) composed of $130 \mathrm{mM} \mathrm{NaCl}, 5.4 \mathrm{mM} \mathrm{KCl}, 1.8 \mathrm{mM} \mathrm{CaCl}_{2}$, $0.8 \mathrm{mM} \mathrm{MgCl}_{2}, 5.5 \mathrm{mM}$ glucose, and $20 \mathrm{mM}$ HEPES-NaOH buffered to 


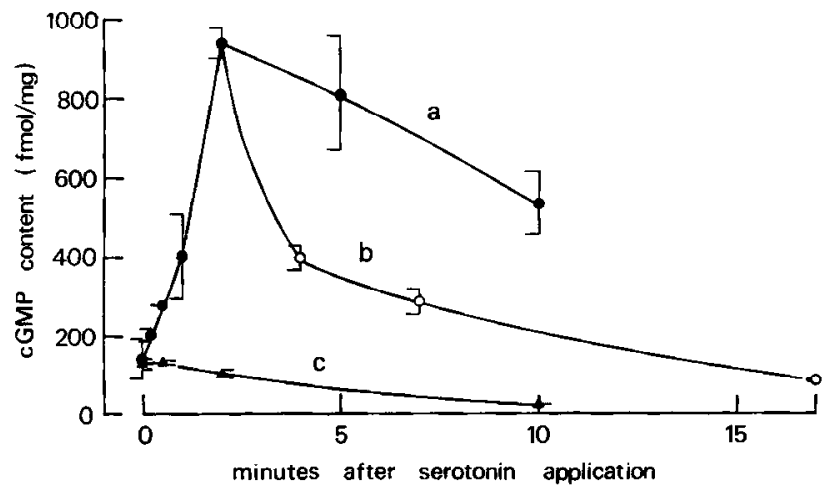

Figure 1. Cellular cGMP contents as a function of time after application of $10^{-6}$ M 5-HT in C6BU-1 cells. Solid circles (curve a) represent a continuous exposure to 5-HT; open circles (curve b) show an accelerated decrease in cGMP content when 5-HT was removed from the bath medium after 2 min; triangles (curve c) show a case in which the bath medium containing 5-HT was deprived of $\mathrm{Ca}^{2+}$ by an addition of EGTA. cGMP contents are expressed as $\mathrm{fmol} / \mathrm{mg}$ of cell protein $(1.0 \times$ $10^{-10} \mathrm{~g}$ protein corresponds to one cell). Three independent series of experiments were performed. All gave equivalent results, and a representative series is shown. Data are means \pm SEM of duplicate or triplicate determinations using a single batch of cell culture.

$\mathrm{pH} 7.3$; in case of reduction of the $\mathrm{Ca}^{2+}$ concentration to $10^{-4}$ and $10^{-5}$ $\mathrm{M}$, EGTA-CaCl ${ }_{2}$ buffer was used. Two minutes after the third wash, the bathing medium was replaced with $1 \mathrm{ml}$ of BSS containing a stimulant (5-HT or ionomycin). To determine the effect of a certain drug, the drug was included in the third wash and thereafter. After a predetermined period of stimulant exposure, the medium was displaced and $400 \mu \mathrm{l}$ of ice-cold 5\% trichloroacetic acid was introduced. Up to this step, the experiment was done in a temperature-regulated room $\left(37^{\circ} \mathrm{C}\right)$. The cells were then collected, sonication-homogenized, and freeze-stored $\left(-80^{\circ} \mathrm{C}\right)$. For immunoassay, the sample was thawed and centrifuged to separate the precipitate. Trichloroacetic acid in the supernatant was removed by repeated extraction with diethylether. After succinylation with succinic anhydride, a $100 \mu \mathrm{l}$ sample was mixed with ${ }^{125}$ I-succinyl cG(A)MP tyrosine methyl ester plus rabbit antiserum against $c G(A) M P$. Fifteen hours later, active carbon was mixed to separate the antigen-bound antibody from the unbound antibody, the radioactivities of which gave the amount of $C G(A) M P$ by the ratio. Protein quantification was by the method of Lowry et al. (1951), and the cellular content of cG(A)MP is expressed as $\mathrm{fmol} / \mathrm{mg}$ protein.

\section{Fluorimetry}

We generally followed the method of Tsien et al. (1982). Briefiy, the cells were collected with a silicon rubber scraper and suspended in BSS at the density of $5 \times 10^{7} \mathrm{cells} / \mathrm{ml}$. Then quin 2 acetoxymethylester (stored at $5 \times 10^{-2} \mathrm{M}$ dissolved in dimethylsulfoxide) was mixed to give the final concentration of $10^{-4} \mathrm{M}$. For control measurements (see below), only the carrier dimethylsulfoxide was mixed. After $80 \mathrm{~min}\left(37^{\circ} \mathrm{C}\right)$ of mild shaking, the cell suspension was diluted with BSS, washed, resuspended $\left(2.5 \times 10^{6} \mathrm{cell} / \mathrm{s} / \mathrm{ml}\right)$, and agitated in a glass vial.

A $2 \mathrm{ml}$ aliquot was transferred in a quartz cuvette after washing and was placed in an Aminco-Bowman SPF-500 spectrofluorimeter incorporating a water circulation jacket for temperature regulation $\left(37 \pm 1^{\circ} \mathrm{C}\right)$ and a built-in magnetic agitator. With monochrometer settings 339 (slit width, 5-10) $\mathrm{nm}$ for excitation and 500 (slit width, 8-15) nm for emission, the fluorescence intensity was continuously recorded. A $20 \mu \mathrm{l}$ stimulant (5-HT, ionomycin, or cyclic nucleotide derivatives at 100fold concentration) was flushed in the cuvette.

To determine the effect of metergoline and verapamil, either drug was added in the cuvette 2 min before the injection of the stimulant. Preliminary examinations revealed that a 2 min exposure (comparable with the previous report-Sugino et al., 1984) was appropriate to obtain the dose-dependent blockage. It may be that the inhibition doses were underestimated, but at exposures $>10 \mathrm{~min}$, a dose-independent blockage became prominent (not shown here). At the end of the recording, $20 \mu \mathrm{l}$ of detergent (Emulgen 810, Kao Soap, Tokyo) was added to disrupt the cells. The fluorescence level was denoted $F_{\max }$. Subsequently, $50 \mu \mathrm{l}$

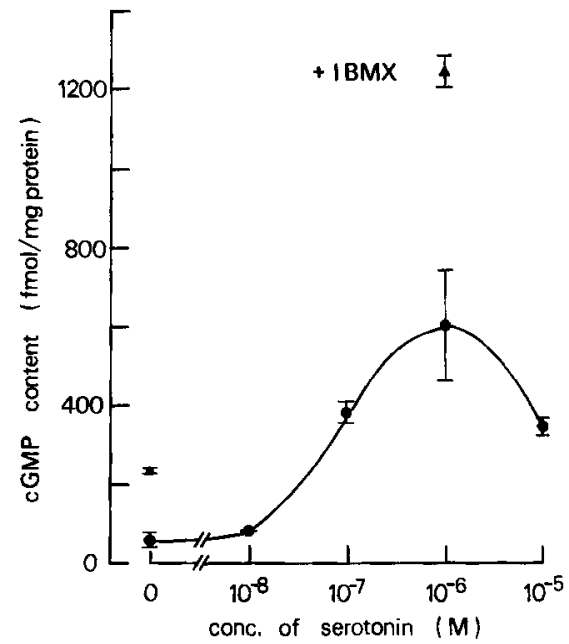

Figure 2. Cellular cGMP contents as a function of concentration of applied 5-HT in C6BU-1 cells. The 5-HT exposure was for $2 \mathrm{~min}$. In the experiment denoted by triangles, $10^{-4} \mathrm{M}$ IBMX was included in the bathing medium beginning $2 \mathrm{~min}$ before the 5-HT exposure (i.e., total time of IBMX exposure, 4 min). Four independent series of experiments were performed, and a representative result is shown. Data are means \pm SEM of duplicate or quadruplicate determinations using a single batch of cell culture.

of $2 \mathrm{M}$ Tris and $75 \mu \mathrm{l}$ of $10^{-1} \mathrm{M}$ EGTA were added to chelate $\mathrm{Ca}^{2+}$ ions. The fluorescence level was designated $F_{\min }$.

The same procedures were repcated using an aliquot of the cell suspension loaded with only dimethysulfoxide. This was for correction of fluorescence signals by quin2-independent signals. The corrected $F_{\text {max }}$ and $F_{\min }$ were designated $F_{\text {max }}$ and $F_{\text {min }}$, respectively. The cytosolic $\mathrm{Ca}^{2+}$ concentration (nM) at an arbitrary time $t\left(\left[\mathrm{Ca}^{2+}\right]_{\mathrm{i}, t}\right)$ was calculated by the formula

$$
\left[\mathrm{Ca}^{2+}\right]_{\mathrm{i}, \mathrm{t}}=115 \times\left(F_{\mathrm{t}}^{\prime}-F_{\text {min }}^{\prime}\right) /\left(F_{\text {max }}^{\prime}-F^{\prime}\right)^{\prime}
$$

where $F^{\prime}$, is the corrected fluorescence level at time $t$. The same experiment was repeated using different cell batches, and a representative result is presented when equivalent results were reproduced.

With our loading conditions, the intracellular quin2 concentration was $0.7-2.0 \times 10^{-3} \mathrm{M}$, as estimated by fluorescence titration. This was done as follows: After the quin2-unloaded cells were disrupted by detergent, quin2 tetrapotassium salt was added until the fluorescence signal reached the same level shown with the detergent-disrupted quin2-loaded cells and the required amount of the quin 2 salt was divided by cell number and cell volume.

\section{Chemicals}

The following chemicals were used: metergoline (Farmitalia, Milan); L-verapamil (Eisai Pharmaceutical, Tokyo); EGTA, quin2 acetoxymethylester, and quin2 tetrapotassium salt (Dojin Chemical, Kumamoto); methysergide (gift of Prof. Shibata of Hawaii Univ.); ionomycin (Calbiochem); and dibutyryl cAMP and dibutyryl cGMP (Yamasa Shoyu, Chiba). Cyproheptadine hydrochloride, 8-bromo cGMP, HEPES, isobutylmethylxanthine (IBMX), DL-propranolol hydrochloride, and serotonin creatinine sulfate were obtained from Sigma. All others were from Wako Chemical, Tokyo.

\section{Results}

Time course of cellular cGMP increase

As seen in Figure 1 (curve $a$ ), when the C6BU-1 cells were exposed to $10^{-6} \mathrm{M}$ 5-HT, the cellular cGMP content increased almost linearly for 2 min until a peak was reached. The peak cGMP content was about 6.6 times the basal (prestimulation) value in this series of experiments. After the peak, the content began to decrease while the cells were still exposed to 5-HT. The magnitude of the cGMP increase varied considerably in 


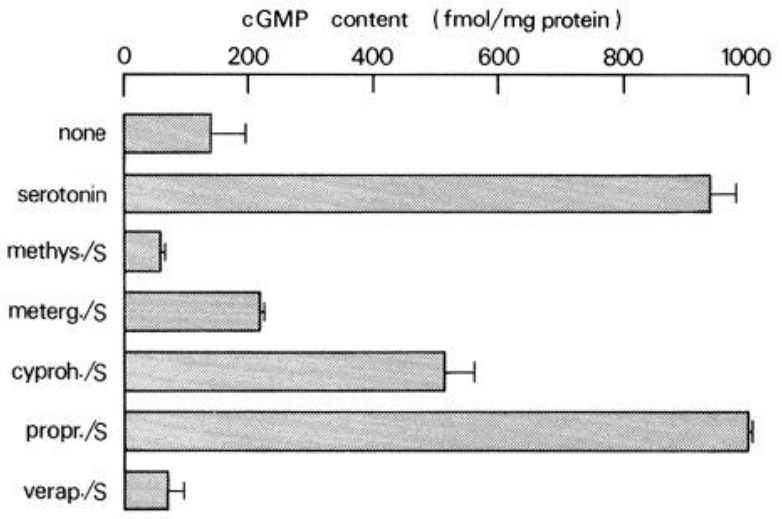

Figure 3. Cellular cGMP contents in C6BU-1 cells 2 min after exposure to $10^{-6} \mathrm{M}$ 5-HT and the effects of 5-HT blockers and a $\mathrm{Ca}^{2+}$ entry blocker. In the results shown in columns 3-7, the indicated drug $\left[10^{-7} \mathrm{M}\right.$ except for verapamil $\left.\left(10^{-5} \mathrm{M}\right)\right]$ was included in the bath medium beginning $2 \mathrm{~min}$ before the 5-HT exposure (i.e., total time of exposure to either drug, $4 \mathrm{~min}$ ). Three and 2 independent series of experiments were repeated for the 5-HT blockers and for verapamil, respectively. The results were equivalent, and a representative series is shown. Data are means \pm SEM of duplicate or quadruplicate determinations using a single batch of cell culture. Abbreviations: methys., methysergide; meterg., metergoline; cyproh., cyproheptadine; propr., propranolol; verap., verapamil; $S$, serotonin.

the series of experiments, mainly because of a fluctuation of the basal value, but its time course was little changed. If the cells were washed at peak time with a BSS containing no 5-HT, the decrease in cGMP content was accelerated (Fig. 1, curve $b$ ).

When $\mathrm{Ca}^{2+}$ was removed from the bathing BSS by a withdrawal of $\mathrm{CaCl}_{2}$ and addition of $10^{-3} \mathrm{M}$ EGTA (estimated free $\mathrm{Ca}^{2+}<10^{-8} \mathrm{M}$ ), the 5-HT-stimulated cGMP increase was totally abolished (Fig. 1, curve $c$ ). A gradual decrease of the basal cGMP content occurred during the 5-HT/EGTA exposure. This decrease was not the effect of 5-HT, since an independent exper-
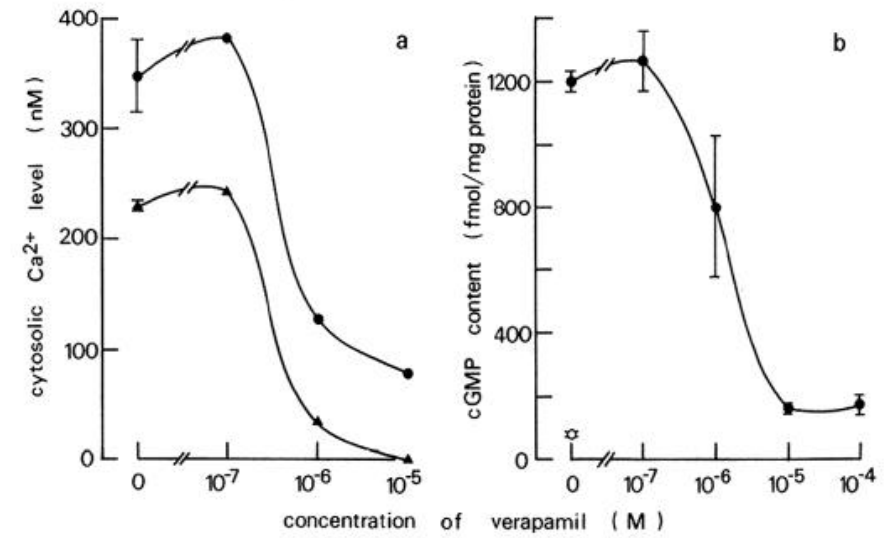

Figure 5. Verapamil blockage of 5-HT-induced increases in the cytosolic $\mathrm{Ca}^{2+}$ level $(a)$ and of cellular cGMP content $(b)$. Verapamil at the indicated concentrations was added to the bath medium beginning $2 \mathrm{~min}$ before 5 -HT $\left(10^{-6} \mathrm{M}\right)$ application. In $a$, peak $\mathrm{Ca}^{2+}$ levels determined by quin 2-fluorimetry are indicated by circles and the net increases (peak minus resting) by triangles. Data are taken from single or duplicate determinations in a batch of cell culture. In $b$, cGMP contents after 2 min exposures to 5-HT are indicated by solid circles and that of cells exposed to a medium containing no 5 - $\mathrm{HT}$ or verapamil by an open circle. Data shown are means and ranges from duplicate determinations using a single batch of cell culture.

iment (not shown here) showed a similar slow decrease caused by $\mathrm{Ca}^{2+}$ depletion.

Application of $10^{-6} \mathrm{M} 5-\mathrm{HT}$ did not affect the cellular content of cAMP (720-870 fmol/mg protein throughout a $5 \mathrm{~min}$ exposure to the stimulant).

Comparison of these results with the time course of the increase in $\left[\mathrm{Ca}^{2+}\right]_{\mathrm{i}}$ induced by 5 -HT (Fig. 1 of Sugino et al., 1984, part of which is reproduced in Fig. 8 of this report), suggests that the production of cGMP was regulated by $\left[\mathrm{Ca}^{2+}\right]_{i}$. The following experiments were done to confirm this.
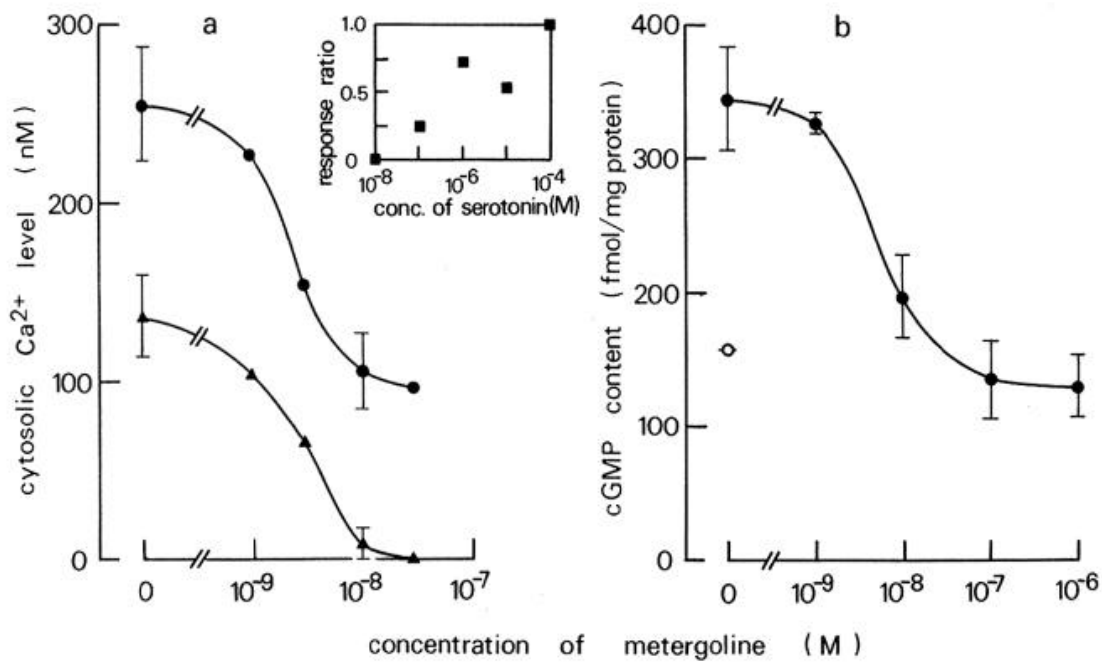

Figure 4. Metergoline blockage of 5-HT-induced increases in cytosolic $\mathrm{Ca}^{2+}$ level $(a)$ and of cellular cGMP content $(b)$ in C6BU-1 cells. Metergoline at indicated concentrations was included in the bath medium beginning 2 min before the 5-HT $\left(10^{-6} \mathrm{M}\right)$ application. In $a$, the peak $\mathrm{Ca}^{2+}$ levels determined by quin 2 -fluorimetry are indicated by circles and the net increases (peak minus resting) of $\mathrm{Ca}^{2+}$ levels by triangles. Data are taken from single or duplicate determinations in a batch of cell culture. Inset, The competitive nature of metergoline blockade on the 5-HT-induced $\left[\mathrm{Ca}^{2+}\right]_{\mathrm{i}}$ increase. The dose of 5-HT was varied from $10^{-7}$ to $10^{-4} \mathrm{M}$ in the presence and absence of $3 \times 10^{-9} \mathrm{M}$ metergoline, and the ratio of net $\left[\mathrm{Ca}^{2+}\right]_{\mathrm{i}}$ increase ( 0 and $1=$ full and no blockade, respectively) was plotted. The cell batch used was different from that in $a$. In $b$, cGMP contents after 2 min exposures to 5-HT indicated by solid circles and that of cells exposed to medium containing no 5-HT or metergoline by an open circle. Data shown are means and ranges from duplicate determinations using a single batch of cell culture. 


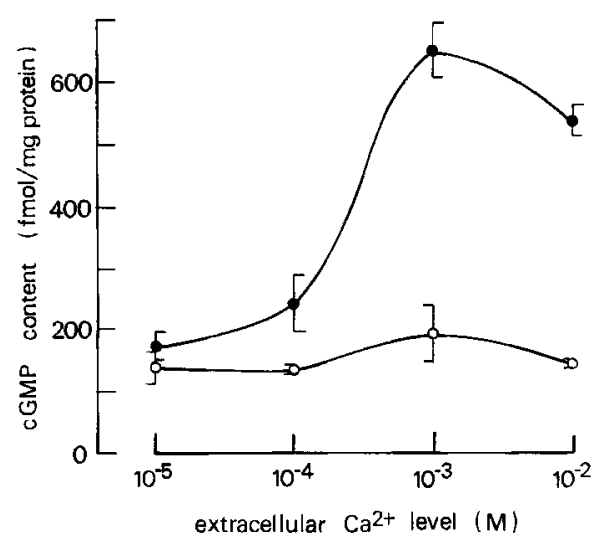

Figure 6. Cellular cGMP contents as a function of extracellular $\mathrm{Ca}^{2+}$ concentration of the bath medium in 5-HT-stimulated C6BU-1 cells The contents after 2 min exposure to 5-HT-containing $\left(10^{-6} \mathrm{M}\right)$ media and to media without 5-HT are indicated by solid and open circles, respectively. Two independent series of experiments were repeated. The results were equivalent, and a representative series is shown. Data are means and ranges from duplicate determinations using a single batch of cell culture.

\section{5-HT dose dependency}

The increase of cellular cGMP content depended on the dose of applied 5-HT (Fig. 2). When the concentration of 5-HT in the medium was varied from 0 to $10^{-5} \mathrm{M}$ for a fixed exposure of $2 \mathrm{~min}$, the effect was maximal at $10^{-6} \mathrm{M}$. At $10^{-5} \mathrm{M}, 5-\mathrm{HT}$ was less effective than that at $10^{-6} \mathrm{M}$. Comparing this result with the 5-HT dose dependence of the increase in $\left[\mathrm{Ca}^{2+}\right]_{\mathrm{i}} \mathrm{re}-$ ported previously (Fig. 2 of Sugino et al., 1984; the $\left[\mathrm{Ca}^{2+}\right]$ increase continued up to $10^{->} \mathrm{M}$ ), suggests that an extremely high $\left[\mathrm{Ca}^{2+}\right]_{i}$ interfered with the cGMP increase.

Figure 2 also shows the effect of $10^{-4} \mathrm{M}$ isobutylmethylxanthine (IBMX), a widely used inhibitor of cyclic nucleotide phos-

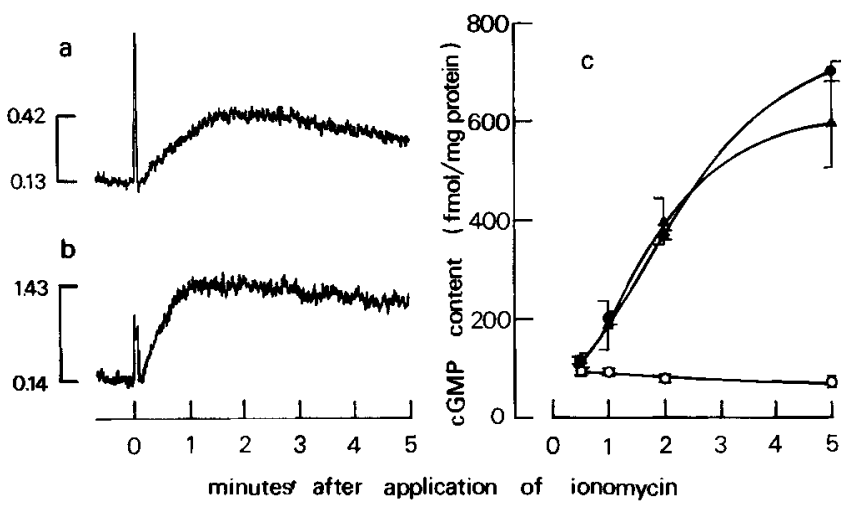

Figure 7. Increases of cytosolic $\mathrm{Ca}^{2+}$ level $(a, b)$ and cellular cGMP content $(c)$ upon applications of ionomycin in C6BU-1 cells. Trace $a$ shows a fluorescence increase induced by exposure to $3 \times 10^{-8} \mathrm{M}$ ionomycin, while trace $b$ shows that induced by $3 \times 10^{-7} \mathrm{M}$ of the ionophore. Transient surges in traces at the moment of application (time 0 ) are an artifact due to contamination by ambient light. The numbers shown beside the traces are the resting and peak $\left[\mathrm{Ca}^{2+}\right]_{\mathrm{i}}(\mu \mathrm{M})$ levels calculated from fluorescence intensities. $c$, Solid circles and triangles indicate the time courses of cGMP increases upon exposure to $3 \times 10^{-8}$ and $3 \times$ $10^{-7} \mathrm{M}$ ionomycin, respectively; open circles show cGMP contents of the cells not exposed to the ionophore. Four and 2 independent series of experiments were performed for $\left[\mathrm{Ca}^{2+}\right]_{\mathrm{i}}$ and cGMP determinations, respectively. Representative data of equivalent series are shown. Data are means and ranges from duplicate determinations using a single batch of cell culture.

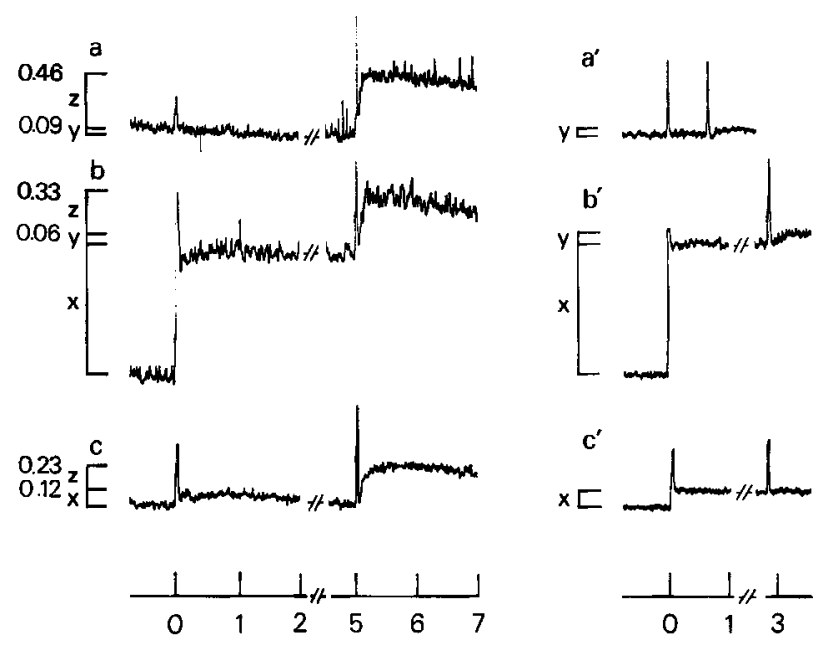

minutes after application of cyclic nucleotide analogs

Figure 8. Fluorimetry in C6BU-1 cells exposed to cyclic nucleotide analogs. At time zero, either dibutyryl cAMP $(a)$, dibutyryl cGMP $(b)$, or 8-bromo cGMP $(c)$ was added to $\left(10^{-3} \mathrm{M}\right.$ in final concentration) a cell suspension loaded with quin2. Five minutes later, 5-HT (final concentrations of $10^{-5} \mathrm{M}$ in $a$ and $b ; 10^{-6} \mathrm{M}$ in $c$ ) was added. Right-hand column, The additions of the cyclic nucleotide analogs and 5-HT were done to the cell suspension without loaded quin2. These procedures segregate quin2-independent (i.e., $\left[\mathrm{Ca}^{2+}\right]_{\mathrm{i}}$-unrelated) fluorescence due to autofluorescences of the analogs (indicated by $x$ ) and of 5-HT (indicated by $y$ ) from the quin2-dependent fluorescence, which exhibits alterations of $\left[\mathrm{Ca}^{2+}\right]_{\mathrm{i}}$ (indicated by $z$ ). The numbers beside traces $a-c$ signify the estimated $\left[\mathrm{Ca}^{2+}\right]_{\mathrm{i}}$ levels $(\mu \mathrm{M})$ before and after the application of 5-HT. Experiments were repeated twice. Representative results are shown.

phodiesterase. IBMX itself ( 4 min exposure) increased the basal cGMP content. But IBMX applied together with $10^{-6} \mathrm{M} 5-\mathrm{HT}$ ( 2 min IBMX alone followed by 2 min IBMX plus 5-HT) caused a more than additive elevation of cGMP content, indicating that a considerable proportion of cGMP formed by guanylate cyclase activated by 5 -HT had been catalyzed by the phosphodiesterase.

\section{Effect of blockers for 5-HT receptor and $\mathrm{Ca}^{2+}$ entry}

As expected from the previous findings that various 5-HT receptor antagonists and $\mathrm{Ca}^{2+}$ entry blockers inhibit the $\left[\mathrm{Ca}^{2+}\right]_{\mathrm{i}}$ elevation and a $\mathrm{Ca}^{2+}$-dependent $\mathrm{K}^{+}$channel activation (Table I of Ogura and Amano, 1984; Fig. 4 of Sugino et al., 1984), the cGMP increase was also suppressed by these antagonists and blockers (Fig. 3). Low doses $\left(10^{-7} \mathrm{M}\right)$ of methysergide, metergoline, and cyproheptadine significantly reduced the effect of 5-HT, while propranolol, a $\beta$-adrenergic antagonist, showed no suppression. Verapamil $\left(10^{-5} \mathrm{M}\right), \mathrm{a} \mathrm{Ca}^{2+}$ blocker, suppressed the cGMP increase.

Dose-dependent inhibitions of the 5-HT-induced $\left[\mathrm{Ca}^{2+}\right]_{\mathrm{i}}$ increase and cGMP accumulation were analyzed in parallel, taking metergoline and verapamil as representatives (Figs. 4 and 5, respectively). (Methysergide was unsuited for $\mathrm{Ca}^{2+}$ fluorimetry due to autofluorescence; inorganic $\mathrm{Ca}^{2+}$ entry blockers such as $\mathrm{Co}^{2+}$ and $\mathrm{Mn}^{2+}$ were also unsuitable, as they bind to quin 2 and quench the fluorescence signal.) Half-inhibition doses of metergoline for the increases in $\left[\mathrm{Ca}^{2+}\right]_{i}$ and cGMP were $3 \times 10^{-9}$ and $5 \times 10^{-9} \mathrm{M}$, respectively. The metergoline blockage of the 5-HT-induced $\left[\mathrm{Ca}^{2+}\right]_{i}$ increase was competitive, since it was attenuated by an increase in the 5-HT dose (Fig. $4 a$, inset). Halfinhibition doses of verapamil for the increases in $\left[\mathrm{Ca}^{2+}\right]_{i}$ and cGMP were $5 \times 10^{-7}$ and $1.2 \times 10^{-6} \mathrm{M}$, respectively. For both drugs, the inhibition dose for the 5-HT-induced cGMP increase 
was slightly higher than that for the $\left[\mathrm{Ca}^{2+}\right]_{\mathrm{i}}$ increase. It is rather difficult to attempt to analyze differences smaller than an order of magnitude.

\section{Dependence on environmental $\mathrm{Ca}^{2+}$}

We showed that total depletion of $\mathrm{Ca}^{2+}$ in the medium abolished the 5-HT response (Fig. 1). To determine the relationship between the environmental $\mathrm{Ca}^{2+}$ level $\left(\left[\mathrm{Ca}^{2+}\right]_{0}\right)$ and the magnitude of the cGMP increasc morc quantitatively, we changed $\left[\mathrm{Ca}^{2+}\right]_{0}$ from $10^{-5}$ to $10^{-2} \mathrm{M}$ using EGTA-CaCl 2 buffer (Fig. 6). The maximal increment was obtained at $10^{-3} \mathrm{M}$ of $\left[\mathrm{Ca}^{2+}\right]_{0}$, and an apparent suppression was seen at $10^{-2} \mathrm{M}$. Since the 5-HT-induced $\left[\mathrm{Ca}^{2+}\right]_{i}$ rise is not suppressed by high $\left[\mathrm{Ca}^{2+}\right]_{0}$ (Sugino et al., 1984), the situation seemed similar to that obtained with excess 5-HT (Fig. 2).

\section{Effect of $\mathrm{Ca}^{2+}$ ionophore}

If the $\left[\mathrm{Ca}^{2+}\right]_{\mathrm{i}}$ rise induced the increase in cGMP, forced entry of $\mathrm{Ca}^{2+}$ by an application of an ionophore should also cause cGMP to increase. Here we used ionomycin as a $\mathrm{Ca}^{2+}$ ionophore. (A23187, a widely used ionophore, was not used because of its autofluorescence.) Fluorimetric recordings in Figure $7(a, b)$ display the time course of the $\left[\mathrm{Ca}^{2+}\right]_{\mathrm{i}}$ rise after application of $3 \times 10^{-8}$ and $3 \times 10^{-7} \mathrm{M}$ ionomycin. In a parallel experiment, the cellular content of cGMP in the C6BU-1 cells did show a gradual increase upon the ionomycin treatment (Fig. $7 c$ ). It should be pointed out again that a higher dose of ionomycin produced a larger $\left[\mathrm{Ca}^{2+}\right]_{\mathrm{i}}$ increase but a smaller cGMP increase.

\section{Effects of cyclic nucleotide analogs}

From the above results, one might postulate that cyclic nucleotide formation remains primarily a result of 5-HT receptor activation and that the $\left[\mathrm{Ca}^{2+}\right]_{i}$ rise (and large-scale cGMP formation through a positive feedback mechanism between $\mathrm{Ca}^{2+}$ and (GMP) is a secondary effect. To exclude this possibility, we applied membrane-permeable derivatives of cAMP and cGMP during the $\left[\mathrm{Ca}^{2+}\right]_{\mathrm{i}}$ fluorimetry (Fig. 8,a-c). No specific $\left[\mathrm{Ca}^{2+}\right]_{\mathrm{i}}$ elevation was induced by either dibutyryl cAMP, dibutyryl cGMP, or 8-bromo cGMP. A stepwise fluorescence increase upon an addition of either drug was attributed to the drug's autofluorescence, since quin2-unloaded cell suspensions showed a fluorescence enhancement of exactly the same magnitude (Fig. 8, $a^{\prime}-c^{\prime}$ ).

\section{Discussion}

\section{Receptor activation and event sequence}

Our present results suggest that the following sequence of events occurs in the C6BU-1 cells: (1) activation of the 5-HT receptor, (2) elevation of $\left[\mathrm{Ca}^{2+}\right]_{i}$, and (3) activation of guanylate cyclase. The dependence of the cGMP increase on the dose of 5-HT (Fig. 2), and the inhibition by 5-HT antagonist (Figs. 3,4 ) indicate the participation of receptors specific to 5 -HT in this response. The inhibition by a $\mathrm{Ca}^{2+}$ entry blocker (Fig. 5) and the dependence of the environmental $\mathrm{Ca}^{2+}$ level (Fig. 6) demonstrate the influx of extracellular $\mathrm{Ca}^{2+}$. The ability of a low dose of $\mathrm{Ca}^{2+}$ ionophore to induce an increase in cGMP (Fig. 7) indicates that the elevated $\left[\mathrm{Ca}^{2+}\right]_{i}$ exerted the role of a messenger in the cGMP formation.

It is of considerable interest to determine which 5-HT receptor subtype is responsible for the present phenomenon. 8-Hydroxydipropylaminotetralin (Sandoz), an agonist reported to bind specifically to the 5- $\mathrm{HT}_{1 \mathrm{~A}}$ subtype (Middlemiss and Fozard, 1983) failed to elevate the $\left[\mathrm{Ca}^{2+}\right]_{i}$ in the concentration range of $10^{-8}$ $10^{-5} \mathrm{M}$ (not shown here). Spiroperidol, which binds with high affinity to the $5-\mathrm{HT}_{2}$ subtype but with low affinity to the $5-\mathrm{HT}_{1}$ subtype (Pedigo et al., 1981; Peroutka and Snyder, 1981), in- hibited the 5-HT-evoked membrane hyperpolarization in the C6BU- 1 cells at a concentration of $10^{-8} \mathrm{M}$ (Ogura and Amano, 1984). Both lines of evidence suggest the participation of the $5-\mathrm{HT}_{2}$-type receptors, but this conclusion is not definitive.

Further studies are needed to determine whether the $\mathrm{Ca}^{2+}$ ion directly activates guanylate cyclase or indirectly induces cGMP accumulation by, for example, inactivation of cyclic nucleotide phosphodiesterase. However, the possibility that $\mathrm{Ca}^{2+}$ could inhibit the phosphodiesterase seems contradictory to the currently accepted concept that $\mathrm{Ca}^{2}+$ binds to calmodulin to activate the enzyme (Teo and Wang, 1973). This possibility can also be tested by application of phosphodiesterase inhibitors such as IBMX and theophylline. A preliminary examination (Fig. 2) showed that $10^{-4} \mathrm{M}$ IBMX applied before 5-HT stimulation failed to cancel, and even accentuated, the effect of 5-HT. This result favors the view that the $5-\mathrm{HT}$-induced $\left[\mathrm{Ca}^{2+}\right]_{i}$ elevation caused primarily the guanylate cyclase activation and secondarily the phosphodiesterase activation. The $\mathrm{Ca}^{2+}$-dependent activation of $\mathrm{CGMP}$ breakdown rationalizes the tendency of extremely high $\left[\mathrm{Ca}^{2+}\right]_{\mathrm{i}}$ to suppress the increase of cellular cGMP as seen when an excess dose of 5-HT, environmental $\mathrm{Ca}^{2+}$ level, or ionophore was applied (Figs. 2, 6, 7).

It was shown recently in human platelets that 5-HT stimulates via activation of the 5- $\mathrm{HT}_{2}$-type receptor, phospholipid turnover, leading to mobilization of $\mathrm{Ca}^{2+}$ and release of arachidonic acid (de Chaffoy de Courcelles et al., 1985). Since arachidonic acid and its metabolites are known to activate the guanylate cyclase in platelets directly (Hidaka and Asano, 1977), an equivalent mechanism may underlie the present 5-HT-evoked response of the C6BU-1 cell.

\section{Cyclic nucleotides in glial cells}

There are few previous reports on receptor-coupled cGMP production in glial cells except for those of Schwartz (1976) and Bottenstein and de Vellis (1978), both of which were conducted with C6 glioma cells. These authors reported that norepinephrine increased cellular cGMP content approximately 10 -fold through activation of $\beta$-receptors. The increase was reduced by about half by a deprivation of $\mathrm{Ca}^{2+}$ from the cell exterior, suggesting the presence of $\mathrm{Ca}^{2+}$-dependent and $\mathrm{Ca}^{2+}$-independent components in the $\beta$-receptor-coupled cGMP production mechanism. In our 5-HT-induced increase of cGMP, however, the withdrawal of $\mathrm{Ca}^{2+}$ from the environment totally abolished the response, suggesting a single $\mathrm{Ca}^{2+}$-dependent component. It might be that norepinephrine caused a $\mathrm{Ca}^{2+}$ release from internal storage sites but that 5 -HT did not.

Bottenstein and de Vellis (1978) also tested the effect of 5-HT and reported an increase of about $33 \%$ in the cellular cGMP content evoked by a $2 \mathrm{~min}$ exposure to $3 \times 10^{-4} \mathrm{M} 5-\mathrm{HT}$. The magnitude of the increase in the present examination was more than 6 times with an applied concentration of $10^{-6} \mathrm{M}$ (Fig. 3). This apparent discrepancy may be the result of phosphodiesterase activation due to an excess elevation of $\left[\mathrm{Ca}^{2+}\right]_{i}$ upon the application of $3 \times 10^{-4} \mathrm{M}$ 5-HT (Fig. 2).

\section{Role of guanylate cyclase in glial cells}

Recently, Zwiller and colleagues $(1981,1984)$ used immunohistochemical methods to show the presence of guanylate cyclase in astroglial cells in vitro and in brain sections. Their biochemical analyses revealed that the astroglial guanylate cyclase activity was lower than the neuronal activity, but that it was still significant. The question then arises as to the role of the glial guanylate cyclase. All discussion remains speculative, since we have no concrete data. It is known that the increase of cellular cAMP due to the activation of adrenergic $\beta$-receptor results in a stimulated breakdown of glycogen in cultured brain astrocytes (Cummins et al., 1983). Morphological changes (protoplasmic form to fibrous one) are induced by a cellular cAMP increase 
(Narumi et al., 1978; Steinbach and Schubert, 1975). These responses would serve as the first steps for analyzing the consequences of cGMP elevation in glial cells.

The increase in glial $\left[\mathrm{Ca}^{2 \dagger}\right]_{i}$ may occur not only by receptor activation but by activation of a voltage-dependent $\mathrm{Ca}^{2+}$ channel whose existence in astroglial membranes was recently shown by MacVicar (1984). $\mathrm{Ca}^{2+}$ is known to play a key role in regulating various cell functions, including mitosis and exo- and endocytosis (Campbell, 1983). The physiological roles of glial guanylate cyclase can better be discussed in the context of $\mathrm{Ca}^{2+}$ regulated cell functions and neuron-glia interactions.

\section{References}

Amano, T., B. Hamprechl, and W. Kemper (1974) High activity of choline acetyltransferase induced in neuroblastoma $\times$ glioma hybrid cells. Exp. Cell Res. 85: 399-408.

Ariano, M. A., L. L. Butcher, and M. M. Appleman (1980) Cyclic nucleotides in the rat caudate-putamen complex: Histochemical characterization and effects of deafferentiation and kainic acid infusion. Neuroscience 5: 1269-1276.

Benda, P., J. Lightbody, G. Sato, L. Levine, and W. Sweet (1968) Differentiated rat glial cell strain in tissue culture. Science $161: 370-$ 371.

Bottenstein, J. E., and J. de Vellis (1978) Regulation of cyclic AMP, cyclic GMP and lactate dehydrogenase by putative neurotransmitters in the C6 rat glioma cell line. Life Sci. 23: 821-834.

Bowman, C. L., and H. K. Kimelberg (1984) Excitatory amino acids directly depolarize rat brain astrocytes in primary culture. Nature 311: 656-659.

Campbell, A. K. (1983) Intracellular Calcium, Wiley, New York.

Cummins, C. J., W. D. Lust, and J. V. Passonneau (1983) Regulation of glycogenolysis in transformed astrocytes in vitro. J. Neurochem. 40: $137-144$.

de Chaffoy de Courcelles, D., J. E. Leysen, F. de Clerck, H. van Belle, and P. A. J. Janssen (1985) Evidence that phospholipid turnover is the signal transducing system coupled to serotonin- $S_{2}$ receptor site. J. Biol. Chem. 260: 7603-7608.

Hidaka, H., and T. Asano (1977) Stimulation of human platelet guanylate cyclase by unsaturated fatty acid peroxides. Proc. Natl. Acad. Sci. USA 74: 3657-3661.

Hirata, H., N. T. Slater, and H. K. Kimelberg (1983) $\alpha$-Adrenergic receptor-mediated depolarization of rat neocortical astrocytes in primary culture. Brain Res. 270: 358-362.

Honma, M., T. Satoh, J. Takezawa, and M. Ui (1977) An ultrasensitive method for the simultaneous determination of cyclic AMP and cyclic GMP in small-volume samples from blood and tissue. Biochem. Med. 18: 257-273

Hösli, L., E. Hösli, U. Schneider, and W. Wiget (1984) Evidence for the existence of histamine $\mathrm{H}_{1}$ - and $\mathrm{H}_{2}$-receptors on astrocytes of cultured rat central nervous system. Neurosci. Lett. 48: 287-291.
Hösli, L., E. Hösli, C. Zehnter, R. Lehmann, and T. W. Lutz (1982) Evidence for the existence of $\alpha$-and $\beta$-adrenoceptors on cultured glial cells-An electrophysiological study. Neuroscience 7: 2867-2872.

Lowry, O. H., N. J. Rosebrough, A. L. Farr, and R. J. Randall (1951) Protein measurement with the Folin phenol reagent. J. Biol. Chem. 193: 265-275.

MacVicar, B. A. (1984) Voltage-dependent calcium channels in glial cells. Science 226: 1345-1347.

Middlemiss, D. N., and J. R. Fozard (1983) 8-Hydroxy-2-(di-n-propylamino)-tetralin discriminates between subtypes of the 5-HT recognition site. Eur. J. Pharmacol. 90: 151-153.

Narumi, S., H. K. Kimelberg, and R. S. Bourke (1978) Effects of norepinephrine on the morphology and some enzyme activities of primary cultures from rat brain. J. Neurochem. 40: 1479-1490.

Ogura. A.. and T. Amano (1984) Serotonin-receptor coupled with membrane electrogenesis in a rat glioma clone. Brain Res. 297: 387391.

Pedigo, N. W., H. I. Yamamura, and D. L. Nelson (1981) Discrimination of multiple $\left[{ }^{3} \mathrm{H}\right]-5$-hydroxytryptamine binding sites by the neuroleptic spiperone in rat brain. J. Neurochem. 36: 220-223.

Peroutka, S. J., and S. Snyder (1981) Two distinct serotonin receptors: Regional variations in receptor binding in mammalian brain. Brain Res. 208: 339-347.

Schwartz, J. P. (1976) Catecholamine-mediated elevation of cyclic GMP in the rat C-6 glioma cell line. J. Cyclic Nucleotide Res. 2: 287296.

Steinbach, J. H., and D. Schubert (1975) Multiple modes of dibutyryl cyclic AMP-induced process formation by clonal nerve and glial cells. Exp. Cell Res. 91: 449-453.

Sugino, H., A. Ogura, Y. Kudo, and T. Amano (1984) Intracellular $\mathrm{Ca}^{2+}$ elevation induced by a neurotransmitter in a glial cell clone. Brain Res. 322: 127-130.

Teo, Y. S., and J. H. Wang (1973) Mechanism of activation of a cyclic adenosine $3^{\prime}: 5^{\prime}$-monophosphate phosphodiesterase from bovine heart by calcium ions. J. Biol. Chcm. 248: 5950-5955.

Trehearne, J. E. (1981) Glial-neurone interactions. J. Exp. Biol. 95: 1-240.

Tsien, R. Y., T. Pozzan, and T. J. Rink (1982) Calcium homeostasis in intact lymphocytes: Cytoplasmic free calcium monitored with new intracellularly trapped fluorescent indicator. J. Cell Biol. 94: 325-334.

Varon, S. S., and G. G. Somjen (1979) Neuron-glia interactions. Neurosci. Res. Prog. Bull. 17: 1-239.

Zwiller, J., M. S. Ghandour, M. O. Revel, and P. Basset (1981) Immunohistochemical localization of guanylate cyclase in rat cerebellum. Neurosci. Lett. 23: 31-36.

Zwiller, J., J.-C. Louis, P. Basset, and G. Vincendon (1984) Neuronal and glial localization and guanylate cyclase: Immunohistochemical evidence in cultured cells. Neurosci. Lett. 49: 51-56. 